\title{
Posttransplant autoimmune encephalitis
}

Devon A. Cohen, MD, A. Sebastian Lopez-Chiriboga, MD, Sean J. Pittock, MD, Avi Gadoth, MD, Anastasia Zekeridou, MD, Barry A. Boilson, MD, William J. Hogan, MB, BCh, John J. Poterucha, MD, Katelynn M. Wilton, Yi Lin, MD, PhD, and Eoin P. Flanagan, MD

Neurol Neuroimmunol Neuroinflamm 2018;5:e497. doi:10.1212/NXI.0000000000000497

The causes of encephalopathy in the posttransplant setting are diverse and include medication toxicity (e.g., posterior reversible encephalopathy syndrome), infections (e.g., human herpes virus type 6 [HHV-6]), and neoplastic disease (posttransplant lymphoproliferative disorder). Autoimmune etiologies are not well recognized in this setting, although a few cases are described. ${ }^{1-5}$ Herein, we report 3 patients with posttransplant autoimmune encephalitis (AE).

\section{Methods}

Standard protocol approvals, registrations, and patient consents

All 3 patients consented to the use of their medical records for research purposes.

\section{Case reports}

We retrospectively identified patients by searching the Mayo Clinic (Rochester, MN) electronic medical record and Neuroimmunology Laboratory database from January 1, 2005, to January 1,2018. Three patients met the inclusion criteria: (1) definite autoimmune encephalitis by 2016 criteria $^{6}$ and (2) neurologic onset after solid-organ or hematopoietic stem cell transplantation (HCT). Neural autoantibody $(\mathrm{Ab})$ testing occurred at the Mayo Clinic Neuroimmunology Laboratory, as previously described. ${ }^{7}$

\section{Case 1}

A 68-year-old Caucasian woman presented with psychosis, orofacial dyskinesias, and memory loss 10 years after a heart transplant for dilated cardiomyopathy. Maintenance immunosuppression at that time included tacrolimus and mycophenolate mofetil. She was initially diagnosed with psychotic depression. MRI revealed subtle right mesial temporal T2-hyperintensity (figure, A). CSF revealed elevations in the white blood cell count $(62 / \mu \mathrm{L}$; normal, $<5)$ and protein level $(59 \mathrm{mg} / \mathrm{dL}$; normal, $<45 \mathrm{mg} / \mathrm{dL}$ ). CSF $\mathrm{N}$-methyl-D-aspartate (NMDA) receptor (R) ab (titer 2 [normal, $<2]$; positive cell-based assay [CBA]) and Epstein-Barr Virus (EBV) PCR were positive, but HHV-6 PCR was negative. PET-CT body was normal. Additional immunosuppressive treatment with IV methylprednisolone (IVMP) $\times 12$ weeks and rituximab $(1 \mathrm{~g} \mathrm{IV} \times 2$ doses) resulted in resolution of psychosis and memory improvement (34/38-38/38 on Kokmen Short Test of Mental Status [STMS]). She was maintained on cyclosporine and mycophenolate. The modified Rankin Scale (mRS) score was 0 at 24 months from onset.

\section{Case 2}

A 61-year-old Caucasian man had subacute memory loss and disorientation 1 month after liver transplant for sclerosing cholangitis. He had received basiliximab and had commenced tacrolimus and mycophenolate mofetil for maintenance immunosuppression. MRI revealed bilateral mesial-temporal T2-signal abnormality (figure, B). The CSF white cell count and protein level were normal, and HHV-6 PCR was negative. Alpha-amino-3-hydroxy-5-methyl-4-isoxazolepropionic acid Receptor (AMPAR) ab was detected in serum (titer $=30,720$; CBA positive) and CSF

\author{
Correspondence \\ Dr. Flanagan \\ flanagan.eoin@mayo.edu
}



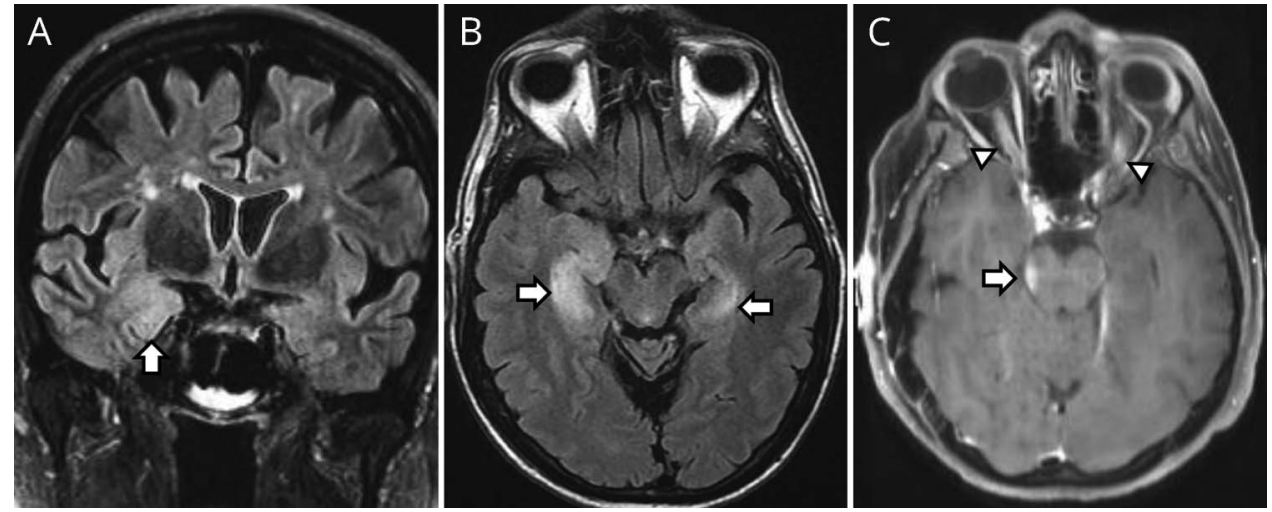

(A) Right mesial temporal T2-hyperintensity (arrow) on coronal Fluidattenuated inversion recovery (FLAIR) in a patient with posttransplant antiNMDA receptor encephalitis. (B) Bilateral (right more than left) mesial temporal T2-hyperintensity (arrows) in a patient with posttransplant antiAMPA receptor encephalitis. (C) Concurrent midbrain enhancement (arrow) and bilateral optic nerve enhancement (arrowheads) in patient with posttransplant myelin oligodendrocyte glycoprotein antibody disease.

(titer = 32; CBA positive). CT body was essentially normal. Additional immunosuppression with IVMP $(1 \mathrm{~g} / \mathrm{d}$ for 5 days and then weekly), plasmapheresis (x5), IVIg ( $0.4 \mathrm{~g} / \mathrm{kg}$ weekly), rituximab ( $1 \mathrm{~g}$ intravenously $\times 2$ doses), and later oral prednisone $(40 \mathrm{mg} / \mathrm{d})$ and a switch from tacrolimus to cyclosporine resulted in improved cognition (26/38-33/38 on Kokmen STMS). Twelve months after onset, his mRS score was 3 .

\section{Case 3}

A 54-year-old Caucasian woman presented with subacute encephalopathy and bilateral vision loss (left > right) 38 months after HCT for multiple myeloma. She was not taking maintenance immunosuppression but had previously received cyclophosphamide, bortezomib, dexamethasone, and melphalan. MRI showed enhancement of the brainstem, thalamus, and optic nerves (figure, C) consistent with acute disseminated encephalomyelitis (ADEM). CSF revealed an elevated white blood cell count $(568 / \mu \mathrm{L} ; 79 \%$ neutrophils $)$ and protein level $(117 \mathrm{mg} / \mathrm{dL})$. Serum myelin oligodendrocyte glycoprotein (MOG) ab was positive by fluorescent-activated cell-sorting live CBA (IgG-binding-index 49.7; normal, <2.5). PET-CT body was normal. Five days of IVMP $(1 \mathrm{~g} / \mathrm{d})$ resolved her encephalopathy, but left eye visual acuity remained 20/400 and the mRS score was 1 at last follow-up, 26 months after onset.

\section{Discussion}

We show that AE can occur posttransplant and highlight the potential benefit of additional immunosuppression, particularly antibody/B-cell depleting therapy. Our identification of 3 patients over a 13-year timeframe at our facility and the few previous reported cases suggests that posttransplant $\mathrm{AE}$ is rare, but could also reflect $\mathrm{AE}$ diagnoses being overlooked in patients receiving immunosuppression.

Each included patient had a neural autoantibody of pathogenic potential with a compatible clinical syndrome (NMDAR: psychosis and orofacial dyskinesia; AMPAR: limbic encephalitis; MOG: ADEM) and improved with additional immunosuppression supporting AE over competing diagnoses. Three case reports of posttransplant anti-NMDAR encephalitis are described. One case occurred 16 months after kidney transplantation for radiation nephropathy preceded by HCT for non-Hodgkin lymphoma; the 2 other cases were after renal transplant for reflux nephropathy and pyelonephritis, respectively ${ }^{2,3}$; all developed $\mathrm{AE}$ while taking immunosuppressants (mycophenolate, 3; prednisone, 2; tacrolimus, 1). Similar to our anti-NMDAR encephalitis patient, 2 cases had concurrent EBV infection detected in CSF potentially suggesting a post-infectious AE similar to post-HSV encephalitis or facilitation by blood-brain barrier breakdown with EBV infection or reactivation. Similar to our case of ADEM with MOG Ab, ADEM cases posttransplant are described, but most reports preceded MOG $\mathrm{Ab}$ availability. ${ }^{1}$ Leucine-rich gliomainactivated 1 (LGI1) ab encephalitis in a child 15 months after HCT for aplastic anemia is also reported. ${ }^{4} \mathrm{HHV}-6$ reactivation is associated with limbic encephalitis posttransplant (particularly HCT), but our patients with limbic encephalitis tested negative. Our report suggests that imbalance between B- and $\mathrm{T}$-cell depletion can provoke autoimmunity, similar to how it occurs with congenital (e.g., Di-George syndrome) and iatrogenic (e.g., alemtuzumab) immunodeficiency.

\section{Author contributions}

D. Cohen: drafting of the manuscript, data acquisition, and analysis and interpretation. A.S. Lopez-Chiriboga, S. Pittock, A. Gadoth, A. Zekeridou, B.A. Boilson, W. Hogan, J.J. Poterucha, K.M. Wilton, and Y. Lin: analysis and interpretation and critical revision of the manuscript. E. Flanagan: study concept and design, analysis and interpretation of data, critical revision of the manuscript, and study supervision.

\section{Study funding}

No targeted funding reported.

\section{Disclosure}

D. Cohen reports no disclosures. S. Pittock provided consultation to Alexion Pharmaceuticals and Medimmune but has received no personal fees or personal compensation for 
these consulting activities. All compensation for consulting activities is paid directly to Mayo Clinic. S. Pittock has received research funding from Grifols, Medimmune, Alexion, and AEA (Autoimmune Encephalitis Associations). A. Gadoth reports no disclosures. A. Zekeridou reports no disclosures. B.A. Boilson reports no disclosures. W. Hogan received research support from Osiris Therapeutics. J.J. Poterucha served on the editorial board of the American Journal of Gastroenterology. K.M. Wilton received research support from the National Institutes of General Medical Sciences. Y. Lin reports no disclosures. E. Flanagan received research support from Medimmune. Full disclosure form information provided by the authors is available with the full text of this article at Neurology.org/NN.
Received June 7, 2018. Accepted in final form June 22, 2018.

\section{References}

1. Caucheteux N, Maarouf A, Daelman L, Toupance O, Lavaud S, Tourbah A. Acute disseminated encephalomyelitis in two renal transplant patients: is there a role for Epstein-Barr virus reactivation? Mult Scler 2013;19:1222-1225.

2. Derksen SJ, Molenaar JP, van der Hoeven JG. Severe anti NMDA encephalitis and EBV infection. Neth J Crit Care 2013;17:19-21.

3. Randall A, Huda S, Jacob A, Larner AJ. Autoimmune encephalitis (NMDAR antibody) in a patient receiving chronic post-transplant immunosuppression. Pract Neurol 2018;18:320-322.

4. Rathore GS, Leung KS, Muscal E. Autoimmune encephalitis following bone marrow transplantation. Pediatr Neurol 2015;53:253-256.

5. Zhao CZ, Erickson J, Dalmau J. Clinical reasoning: agitation and psychosis in a patient after renal transplantation. Neurology 2012;79:e41-e44.

6. Graus F, Titulaer MJ, Balu R, et al. A clinical approach to diagnosis of autoimmune encephalitis. Lancet Neurol 2016;15:391-404.

7. Dubey D, Pittock SJ, Kelly CR, et al. Autoimmune encephalitis epidemiology and a comparison to infectious encephalitis. Ann Neurol 2018;83:166-177. 


\section{Neurology \\ Neuroimmunology \& Neuroinflammation}

Posttransplant autoimmune encephalitis

Devon A. Cohen, A. Sebastian Lopez-Chiriboga, Sean J. Pittock, et al.

Neurol Neuroimmunol Neuroinflamm 2018;5;

DOI 10.1212/NXI.0000000000000497

This information is current as of August 20, 2018

Updated Information \&

Services

References

Citations

Subspecialty Collections

Permissions \& Licensing

Reprints including high resolution figures, can be found at:

http://nn.neurology.org/content/5/6/e497.full.html

This article cites 7 articles, 1 of which you can access for free at: http://nn.neurology.org/content/5/6/e497.full.html\#\#ref-list-1

This article has been cited by 3 HighWire-hosted articles: http://nn.neurology.org/content/5/6/e497.full.html\#\#otherarticles

This article, along with others on similar topics, appears in the following collection(s):

Autoimmune diseases

http://nn.neurology.org//cgi/collection/autoimmune_diseases

Information about reproducing this article in parts (figures,tables) or in its entirety can be found online at:

http://nn.neurology.org/misc/about.xhtml\#permissions

Information about ordering reprints can be found online:

http://nn.neurology.org/misc/addir.xhtml\#reprintsus

Neurol Neuroimmunol Neuroinflamm is an official journal of the American Academy of Neurology.

Published since April 2014, it is an open-access, online-only, continuous publication journal. Copyright

Copyright (C) 2018 The Author(s). Published by Wolters Kluwer Health, Inc. on behalf of the American

Academy of Neurology.. All rights reserved. Online ISSN: 2332-7812.

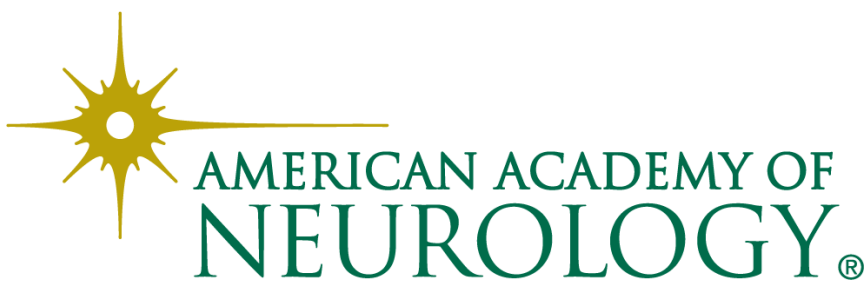

